Int. J. Morphol.,

31(1):94-99, 2013.

\title{
Radiologic Evaluation of Clavicular Morphology in Southern Nigerians
}

\author{
Evaluación Radiólogica de la Morfología Clavicular en Nigerianos del Sur
}

\author{
A. I. Udoaka \& A. U. Nwokediuko
}

UDOAKA, A. I. \& NWOKEDIUKO, A. U. Radiologic evaluation of clavicular morphology in southern Nigerians. Int. J. Morphol., 31(1):94-99, 2013.

SUMMARY: This study was carried out to derive empirical values and indices for which clavicles on a radiograph can be correctly sexed. 1000 radiographic left clavicles of adults of both sexes (500 males and 500 females) ranging from ages $25-60$ yrs collated from the Radiology departments of University of Port Harcourt Teaching Hospital, University of Calabar Teaching Hospital and The General Hospital Calabar, all in Southern Nigeria, were used in this study. The values obtained in this study showed that, the males had Sternal head length of $2.52 \pm 0.33 \mathrm{~cm}$, Acromial head length of $1.66 \pm 0.25 \mathrm{~cm}$, a mid shaft diameter of $2.01 \mathrm{~cm}$ and body length of $15.28 \pm 0.66 \mathrm{~cm}$. The female Sternal head length was $2.18 \pm 0.37 \mathrm{~cm}$, Acromial head length was $1.65 \pm 0.22 \mathrm{~cm}$, mid shaft diameter was 1.48 $\mathrm{cm}$ and the mean body length was $14.56 \pm 0.51 \mathrm{~cm}$. The sternal head of the males was significantly longer than the females $(\mathrm{P}<0.001)$ but the body and acromial head lengths were not. The length / mid shaft diameter ratio and the product of the length and mid shaft diameter were also derived. The use of the demarking point analysis to identify sex showed very low percentages in all the parameters studied.

KEYWORDS: Clavicle; Radiographs; Demarking point.

\section{INTRODUCTION}

The clavicle is the bony connection between the upper limb and the trunk. It has a shaft and two ends (Totter \& Peterson, 1996). It articulates with the acromium of the scapula laterally and the sternum medically and it is also said to vary in shape more than other long bones (Ellis, 2002; Romans, 2003; Moore \& Dalley, 2006).

Clavicle is the first foetal bone to undergo primary ossification and it is the last bone to completely ossify (Stranding et al., 2005; Scheuer \& Black, 2000; Kreitner et al., 1998). Complete fusion occurs between the ages of 2230 years, its medical epiphysis being the last to fuse (Scheuer $\&$ Black). The medial clavicular epiphysis has been established as a reliable parameter in assessing the aging method of young adults and variations in skeletal maturation have been attributed to ethnic differences (Schaefer \& Black, 2005).

The anthropometry of the clavicle has been of interest of the study to several researchers (Parsons, 1916; Terry, 1932; Singh, 1969; Jit \& Sahni, 1983; Frutos, 2002). The parts of the clavicle used were the length, mid shaft diameter and circumference, sternal head length, acromial head length and the medial and lateral angles. Racial differences have been observed by these early researchers in the clavicular measurements and reference values have been set for some races. Terry studied the white and black Americans in 1932, a review of his values was done 40 years after by Singh in 1972 on the same ethnic Americans. The values of Singh were slightly different from those of Terry but not significant. Terry had noted that in male and female American Negroes and in male American whites, the left bone was longer than the right but not statistically significant. He also observed that the clavicles of American negroes were longer than those of the American whites. Oliver (1951) also studied the length of the clavicle in French people and observed that in an individual, the left clavicle was usually longer than the right. He pointed out that the length of the clavicle was not the same even in closely related racial groups, the average length of the bone was different in different races. Parsons had also set standards for the English. Other studies done in India by Singh \& Grangrade (1968) and Kaur et al., (2002) also noted that in various zones of India, the length of the 
clavicles of the Northwest zone of Chandigraph were longer than the Amritsar and the Varansi zones. All the workers agreed that female clavicles were significantly shorter by about $10 \%$ than those of the males $(\mathrm{P}<0.005)$. The length of the adult left clavicle was always more than that of the right side, this was attributed to the use of the right hand in right handed individuals, the curve of the right clavicle in adults becomes greater than that of the left side which leads to a shorter right bone as compared to the left, this difference was however not statistically significant $(\mathrm{P}>0.05)$. In all these studies, the skeletal clavicle was used.

McCormick et al., (1991) went further and was also able to show sexual dimorphism in the clavicle using a combination of length and mid shaft circumference measurements. He gave a significant cut off value of 43 from the length - circumference product and was able to predict sex in $93 \%$ of the entire study population with values less than 43 for females and above 43 for males in the North American population. Singh \& Jit (1996) assessed the volume of the clavicle by the water displacement method and found that using all the parameters in a multivariate analysis gave better sex identification than using a single parameter.

The presence of the Rhomboid fossa on the clavicle has also been used as a sex and age estimator. Rogers $e t$ al., (2000). In their study they found out that the presence of rhomboid fossa was more in males and could be used for sex identification. Kaur \& Jit (1990) also used the cortical index of the clavicle which is the proportion of the cortical thickness to the total diameter of the bone and found out the index increased from ages 15-30 years and thereafter decreased steadily from age 41 years, the rate of decrease was a lot more in females than in males and this difference was also found to be significant. Antropometric studies of the clavicles using radiographs have also been done. McGraw et al., (2009) found out in their measurement of the length of the clavicle on chest radiographs in children that females achieved $80 \%$ of their clavicular length by the age of 9 years while that of the boys was at 12 years, they therefore attributed the longer lengths in adult males to this finding.

There has not been any reported work done on the anthropometry of the Clavicle in the Niger Delta region of Nigeria to the best of our knowledge. This study was aimed at knowing the clavicular dimensions of the people of Southern Nigeria who are predominantly Ijaws and to find out if there are differences in the values from quoted standard values of other races. The demarking point analysis will also be used in an attempt to sex the clavicles in this sub region of Nigeria.

\section{MATERIAL AND METHOD}

A total of 1000 standard posterior-anterior radiographs comprising 500 males and 500 females of the chest with visible and clearly represented clavicles and radiographs of the clavicles for suspected fractures were utilized in this study. The radiographs were obtained by random selection from the archives of the Radiology departments of the University of Port Harcourt Teaching Hospital, Port Harcourt and the University of Calabar Teaching Hospital, Calabar and the General Hospital Calabar. The radiographs were all normal and of adults with age ranging from 25-60 years, only films showing complete secondary ossification of the clavicle were used. The records of the biodata of the subjects all indicated people of Southern Nigerian origin.

The materials used were the $\mathrm{x}$-ray viewing box and the metric rule. The radiographs were viewed and marked on transparencies placed on each film for tracing. Only the left clavicle was measured. The following lines were traced and measured.

The highest vertical extent to the lowest of the sternal head is designated Sternal head length (SHL)

The superior borderline of the middle point of the shaft of the clavicle to the inferior borderline of the same is designated mid-shaft diameter (MSD)

The highest vertical extent to the lowest extent of the acromial head is designated the Acromial head length (AHL).

The length of the clavicle was taken as the horizontal line drawn from the most medial point on the medial boarder of the sternal end to the most lateral point of the lateral boarder of the acromial end.

The ratio of the length of the clavicle to the midshaft diameter (L/MSD) and the product of the length of the clavicle and the mid-shaft diameter (L X MSD) were calculated for all the radiographs utilized for the study. Statistical analysis was done to determine the mean, standard deviation and the identification points of all the radiographs. Further evaluation carried out included a test of significance and the demarking points of both sexes.

\section{RESULTS}

The values for all the parameters are as shown in Tables I-III. The mean value for the length of the clavicle in 
males was $15.28 \pm 1.3 \mathrm{~cm}$ while that of the females was $14.50 \pm 0.5 \mathrm{~cm}$. This difference was not statistically significant $(\mathrm{P}>0.05)$. The acromial head length was also insignificantly larger in the males. The sternal head length and the mid shaft diameter were however significantly larger in the males than in the females.

Further evaluation of the ratio of length to mid shaft diameter showed highly significant values with the females having higher values. On the other hand the product of the length and the mid shaft diameter showed higher males values which were also significant.

Identification point which is derived from the normal range in the sample and the demarking point analysis $($ mean $+3 \mathrm{SD})$ revealed very low percentages that can be identified of the sexes in all the parameters. This will be discussed.

Table I. Mean dimensions and SD of the left Clavicle, identification point, percentages identified and test of significance in both sexes in all the parameters studied.

\begin{tabular}{|c|c|c|c|c|c|c|c|c|}
\hline $\mathbf{S} / \mathbf{N}$ & Parameters & Sex & Range (cm) & Mean $(\mathrm{cm})$ & SD & IP Value & $\begin{array}{c}\text { \%bone } \\
\text { identified }\end{array}$ & P Value \\
\hline \multirow[t]{2}{*}{1} & Sternal head lenght & M & $1.6-3.2$ & 2.5 & 0.3 & $>2.8$ & 18.6 & \multirow{2}{*}{$\begin{array}{l}Z=18.78 \\
P<0.005\end{array}$} \\
\hline & & $\mathrm{F}$ & $1.4-2.8$ & 2.1 & 0.37 & $<1.6$ & 8 & \\
\hline \multirow[t]{2}{*}{2} & Acromial head lenght & M & $1.2-2.3$ & 1.65 & 0.2 & $>2.0$ & 1.4 & \multirow{2}{*}{$\begin{array}{l}Z=1.25 \\
P>0.05\end{array}$} \\
\hline & & $\mathrm{F}$ & $1.2-2.0$ & 1.60 & 0.2 & $<1.2$ & 0 & \\
\hline \multirow[t]{2}{*}{3} & Lenght of clavicle (L) & M & $13.4-17$ & 15.28 & 1.3 & $>15.5$ & 38.6 & \multirow{2}{*}{$\begin{array}{c}Z=1.3 \\
P>0.05\end{array}$} \\
\hline & & $\mathrm{F}$ & $13.4-15.5$ & 14.50 & 0.5 & $<13.5$ & 0 & \\
\hline \multirow[t]{2}{*}{4} & Mid shaft diameter (MSD) & M & $1.4-2.6$ & 2.01 & 0.3 & $>2.1$ & 32 & \multirow{2}{*}{$\begin{array}{l}Z=24.88 \\
P<0.005\end{array}$} \\
\hline & & $\mathrm{F}$ & $1.0-2.1$ & 1.48 & 0.37 & $<1.4$ & 30.2 & \\
\hline \multirow[t]{2}{*}{5} & L/MSD & M & $5.4-11.4$ & 7.74 & 1.17 & $<7.45$ & 38.2 & \multirow{2}{*}{$\begin{array}{l}Z=25.98 \\
P<0.005\end{array}$} \\
\hline & & $\mathrm{F}$ & $7.45-13.7$ & 10.06 & 1.62 & $>11.4$ & 18.2 & \\
\hline \multirow[t]{2}{*}{6} & L X MSD & M & $20.3-43.94$ & 30.85 & 4.97 & $>32.22$ & 34.4 & \multirow{2}{*}{$\begin{array}{l}Z=11.28 \\
P<0.005\end{array}$} \\
\hline & & $\mathrm{F}$ & $13.9-32.22$ & 21.55 & 3.48 & $<20.3$ & 44 & \\
\hline
\end{tabular}

Table II. Mean dimensions and SD of the left Clavicle, the demarking point and percentage identified by the demarking point in all the parameters studied in both sexes.

\begin{tabular}{|c|c|c|c|c|c|c|c|}
\hline S/No & Parameters & Sex & Mean & SD & $\begin{array}{l}\text { Calculated } \\
\text { Mean+3SD }\end{array}$ & DP & $\begin{array}{c}\% \text { Bone } \\
\text { identified by DP }\end{array}$ \\
\hline \multirow[t]{2}{*}{1} & \multirow[t]{2}{*}{ S ternal Head lenght } & M & 2.5 & 0.3 & $0.7-3.4$ & $>3.21$ & 0 \\
\hline & & $\mathrm{F}$ & 2.1 & 0.37 & $0.9-3.2$ & $<1.62$ & 8 \\
\hline \multirow[t]{2}{*}{2} & \multirow[t]{2}{*}{ Acromial Head lenght } & M & 1.65 & 0.2 & $1.05-2.25$ & $>2.2$ & 0 \\
\hline & & $\mathrm{F}$ & 1.60 & 0.2 & $1.0-2.2$ & $<1.05$ & 0 \\
\hline \multirow[t]{2}{*}{3} & \multirow[t]{2}{*}{ Length of clavicle (L) } & M & 15.28 & 1.3 & $11.38-19.18$ & $>16$ & 5.4 \\
\hline & & $\mathrm{F}$ & 14.5 & 0.5 & $13.0-16.0$ & $<11.38$ & 0 \\
\hline \multirow[t]{2}{*}{4} & \multirow[t]{2}{*}{ Mid-shaft diameter (MSD) } & M & 2.01 & 0.3 & $1.11-2.91$ & $>2.59$ & 2.2 \\
\hline & & $\mathrm{F}$ & 1.48 & 0.37 & $0.37-2.59$ & $<1.11$ & 5.2 \\
\hline \multirow[t]{2}{*}{5} & \multirow[t]{2}{*}{ L/MSD } & M & 7.74 & 1.17 & $4.23-11.25$ & $<5.2$ & 0 \\
\hline & & $\mathrm{F}$ & 10.06 & 1.62 & $5.2-14.92$ & $>11.25$ & 19.6 \\
\hline \multirow[t]{2}{*}{6} & \multirow[t]{2}{*}{ L X MSD } & M & 30.85 & 4.97 & $15.94-45.76$ & $>31.99$ & 4.4 \\
\hline & & $\mathrm{F}$ & 21.55 & 3.48 & $11.11-31.99$ & $<15.94$ & 2.6 \\
\hline
\end{tabular}




\section{DISCUSSION}

The role of the skeleton in estimating attributes such as age sex, race and stature have been studied extensively and more so using radiographs (Mora et al., 2001; Scheafer \& Blank, 2005). The clavicle has been described as a useful bone for the determination of sex and age in a several populations (Kreitner et al.; Murphy, 2002; Kaur \& Jit), some of the authors used the discriminant function analysis to study sexual dimorphism (Frutos) while others used the demarking point analysis (Jit \& Singh, 1966; Singh \& Gangrady). There is however paucity of work done on the morphometry of the clavicle in Nigerians. The mean clavicle length in males in this study was $152.80 \mathrm{~mm}$ while that of females was 145.0 $\mathrm{mm}$, this result so obtained has corroborated with the findings of earlier workers that the clavicle is longer in the males than the females (Parsons; Terry; Oliver; Kaur et al.). This difference in this present study was however insignificant. The left clavicle was studied in this research work. The values of the length of the clavicle in this study compared to the corresponding side of earlier workers of other population showed marked racial variation. Our value of $152.80 \mathrm{~mm}$ for the males was only similar to those of the USA males who had slightly higher values with a difference of only $0.57 \mathrm{~mm}$ (Singh). The English (Parson), USA negroes (Singh) and the French men (Oliver) also had longer clavicles. On the other hand the Indians had shorter Clavicles (Jit \& Singh; Kaur et al.).

Oliver in a comparative study of the clavicular length of the French people and reported values of other workers came to the conclusion that the length of the clavicle was not the same even in closely related groups. He further observed that the people of Finland and the Japanese had similar lengths and inferred that widely separated and unrelated races might even have similar lengths. Our present study has also found a similarity with the USA whites in the lengths of the male clavicles.

Table III. Mean length of left Clavicle in both sexes in other populations compared to the present study.

\begin{tabular}{lcc}
\hline Population & \multicolumn{2}{c}{ Mean length of the left clavicle ( mm) } \\
\cline { 2 - 3 } & Males & Females \\
\hline English (Parsons, 1916) & 154 & 139 \\
USA Whites (Singh, 1972) & 153.37 & 134.84 \\
USA Negrose (Singh, 1972) & 157.32 & 140.80 \\
French (Oliver, 1951) & 155.00 & 138.70 \\
India (North west) (Kaur et al., 2000) & 151.14 & 134.00 \\
India (Amntsar zone) (Jit \& Singh, 1966) & 147.59 & 129.80 \\
Present study & 152.80 & 145.00 \\
\hline
\end{tabular}

The female claviclular length in our study was 145.0 $\mathrm{mm}$ which is similar to only the USA negroid females who had a recorded value of $140.0 \mathrm{~mm}$. Our female value was the largest in all the population compared with. It is therefore not surprising that the difference between our males and females was not statistically significant unlike all the earlier workers who studied other populations. The female clavicle in this study was only shorter by about $2.6 \%$ as against about $10 \%$ recorded for the Indians (Kaur et al.). Using the identification point of $>15.5 \mathrm{~mm}$, the length of the clavicle can identify about $38.6 \%$ of the males as the maximum value for female was found to be $15.5 \mathrm{~mm}$. Subjected to further statistical analysis of demarking point, only $5.4 \%$ of the males can be identified with $99.7 \%$ accuracy. The females could not be identified by either the identification point or the demarking point in using the length of the clavicle alone in the study population. This was also the report of Stewart (1979) who stated that in $78 \%$ of the sample there was an overlap of values for males and females as a result suggested that the value of discriminating sex by clavicular length is relatively low and was earlier noted by Jit \& Singh who introduced the used of demarking point. In their work only $11.5 \%$ identification for females and $19.8 \%$ identification for males could be attributed to the length of the clavicle.

The Acromial head length showed only a slightly higher value for males, the difference in the means being only $0.5 \mathrm{~mm}$ and statistically insignificant. The percentage of bone identified by both identification point and demarking point was almost nil.

The sternal head length on the other hand showed a significantly higher value in the males. Percentages of bone identifiable was also poor with identification point giving less than $20 \%$ for males and $8 \%$ for females while the demarking point was about $3 \%$ in male clavicle identification and less than $2 \%$ for females. This fact was also noted by Murphy in New Zealand.

The mid shaft diameter was the most significant single parameter $(z=24.88)$ of all the single parameters in sexual dimorphism. The males had higher values $(2.01 \mathrm{~cm})$ than the females $(1.48 \mathrm{~cm})$. This is in keeping with the report of Strandring et al. 
The ratio of the length of the clavicle and the mid shaft diameter (L/MSD) yielded very interesting results. The female had higher values of $10.06 \pm 1.62 \mathrm{~cm}$ compared to the males that had $7.74 \pm 1.17 \mathrm{~cm}$. This difference was highly significant $\mathrm{P}<0.005$. The product of length and the mid shaft diameter was more in the males with the males having $30.85 \pm 4.97 \mathrm{~cm}$ while the females had $21.55 \pm 3.48$ $\mathrm{cm}$. The L/MSD could identify up to $38.2 \%$ in males and $18.2 \%$ in females despite the overlap. The L X MSD could identify $34.4 \%$ males and $44 \%$ females using the identification point analysis but on using the demarking point the L/MSD ratio yielded the highest percentage $(19.6 \%)$ of bone identification in females of all the parameters while the LXMSD could only identify about $2 \%$ females. None of the male clavicles could be identified by the L/MSD ratio and only $4.4 \%$ was identifiable by the LXMSD. This fact was also reported by Strandring $e t$ al.

In Conclusion, the clavicular parameters showed low percentages of identifying sex in the Southern Nigerian population by the demarking point analysis method.

UDOAKA, A. I. \& NWOKEDIUKO, A. U. Evaluación radiólogica de la morfología clavicular en nigerianos del sur. Int. J. Morphol., 31(1):94-99, 2013.

RESUMEN: Este estudio fue realizado para obtener los valores empíricos e índices para que clavículas puedan ser correctamente sexuadas radiográficamente. Fueron utilizadas 1000 radiografías de clavículas del lado izquierdo de individuos adultos (entre 25 y 60 años de edad) de ambos sexos (500 hombres y 500 mujeres), recolecadas por los departamentos de radiología de la Universidad Port Harcourt Teaching Hospital, Universidad Calabar Teaching Hospital y Hospital General de Calabar, todos ellos del sur de Nigeria. Los valores obtenidos mostraron que los hombres tenían una longitud de la extremidad esternal de 2,52 $\pm 0,33 \mathrm{~cm}$, y de la extremidad acromial

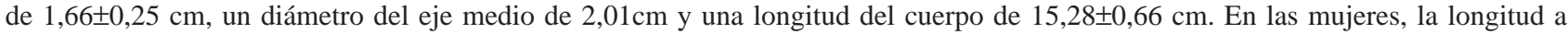
extremidad esternal fue de $2,18 \pm 0,37 \mathrm{~cm}$, de la extremidad acromial de $1,65 \pm 0,22 \mathrm{~cm}$, un diámetro del eje medio de $1,48 \mathrm{~cm}$ y una longitud del cuerpo promedio de 14,56 $\pm 0,51 \mathrm{~cm}$. La extremidad esternal de los hombres era significativamente más larga que en mujeres ( $<<0,001)$, pero no la longitud del cuerpo y la extremidad acromial. Fueron obtenidas la relación longitud/diámetro del eje medio y el producto de la longitud y diámetro del eje medio. El uso del análisis del punto de demarcación para diferenciar el sexo presentó porcentajes muy bajos en todos los parámetros estudiados.

PALABRAS CLAVE: Clavícula; Radiografías; Punto de demarcación.

\section{REFERENCES}

Ellis, H. Clinical Anatomy: A revision and applied anatomy for clinical students. 10 ${ }^{\text {th }}$ Ed. Oxford, Blackwell Publishing, 2002. pp.181-2.

Frutos, L. R. Determination of sex from the clavicle and scapula in a Guatemalan contemporary rural indigenous population. Am. J. Forensic Med. Pathol., 23(3):284-8, 2002.

Jit, I. \& Sahni, D. Sexing the north Indian clavicles. J. Anat. Soc. India, 32(2):61-72, 1983.

Jit, I. \& Singh, S. The sexing of the adult clavicles. Indian J. Med. Res., 54(6):551-71, 1966.

Kaur, H.; Harject, S. D. \& Jit, I. Length and curves in the Northwest Indians. J. Anat. Soc. India, 51(2):7-12, 2002.

Kaur, H. \& Jit, I. Age estimation from cortical index of the human clavicle in northwest Indians. Am. J. Phys. Anthropol., 83(3):297-305, 1990.

Kreitner, K. F.; Schweden, F. J.; Riepert, T.; Nafe, B. \& Thelen, M. Bone age determination based on the study of the medial extremity of the clavicle. Eur. Radiol., 8(7):1116-22, 1998.
McGraw, M. A.; Mehlman, C. T.; Lindsell, C. J. \& Kirby, C. L. Postnatal growth of the clavicle: birth to 18 years of age. $J$. Pediatr. Orthop., 29(8):937-43, 2009.

McCormick, W. F.; Stewart, J. H. \& Greene, H. Sexing of human clavicles using length and circumference measurements. Am. J. Forensic Med. Pathol., 12(2):175-81, 1991.

Moore, K. L. \& Dalley, A. F. Clinically Oriented Anatomy. 5th Ed. Baltimore, Lippincott Williams \& Wilkins, 2006. pp.729, 747, 875 .

Mora, S.; Boechat, M. I.; Pietka, E.; Huang, H. K. \& Gilsanz, V. Skeletal age determinations in children of European and African descent: applicability of the Greulich and Pyle standards. Pediatr. Res., 50(5):624-8, 2001.

Murphy, A. M. Articular surfaces of the pectoral girdle: sex assessment of prehistoric New Zealand Polynesian skeletal remains. Forensic Sci. Int., 125(2-3):134-6, 2002.

Olivier, G. Anthropologie de la Clavicule. III, La Clavicule due Francis. Bull. Mem. Soc. Anthropol. Paris, 2:121-57, 1951. 
Parsons, F. G. On the Proportions and Characteristics of the Modern English Clavicle. J. Anat., 51(Pt 1):71-93, 1916.

Romans, G. J. Cunnigham's Manual of Practical Anatomy. Vol. 1. Upper and Lower Limbs. 15th Ed. Oxford, University Press, 2003.

Rogers, N. L.; Flournoy, L. E. \& McCormick, W. F. The rhomboid fossa of the clavicle as a sex and age estimator. J. Forensic Sci., 45(1):61-7, 2000.

Schaefer, M. C. \& Black, S. M. Comparison of ages of epiphyseal union in North American and Bosnian skeletal material. $J$. Forensic Sci., 50(4):777-84, 2005.

Scheuer, L. \& Black, S. Developmental Juvenile Osteology. London, Academic Press, 2000. p.252.

Singh, S. \& Gangrade, K. C. The sexing of adult claviclesverification and applicability of demarking points. Indian Acad. Forensic Sci., 7:20-3, 1968.

Singh, D. \& Jit. I. Identification of sex from volume of the clavicle. J. Anat. Soc. India, 45(2):119-24, 1996.

Singh, S. Sexing of American Clavicles. J. Anat. Soc. India, 18:256, 1996.

Standring, S.; Ellis, H.; Healy, J. C.; Johnson, D.; Williams, A.; Collins, P. \& Wigley, C . Gray's Anatomy. The Anatomical Basis of Clinical Practice. 39th ed. London, Elsevier Churchill Livingstone, 2005. pp.817-9.

Stewart, T. D. Essentials of Forensic Anthropology. Springfield, Charles C., 1979.

Terry, R. J. The clavicle of the American negro. Am. J. Phys. Anthropol., 16(3):351-80, 1932.

Trotter, M. \& Peterson, R. R. In Morris's Human Anatomy. Anson, B. J. (Ed.). 12th Ed. New York, McGraw-Hill, 1966. p.244.

\section{Correspondence to: Dr. (Mrs.) A. Udoaka, FWACS Department of Anatomy College of Health Sciences University of Port Harcourt Port Harcourt \\ NIGERIA}

Tel: $234(0) 8030849208$

Email: alabaudoaka@yahoo.com

Received: 04-06-2011

Accepted: 03-09-2012 